\title{
Influences of Flux Waveform on Magnetostriction of Silicon Steel Strip and Noise of Transformer Core
}

\author{
Kunihiro Shinya Member (Fukui National College of Technology) \\ Koichi Saitoh Member (Fukui National College of Technology)
}

Keywords: flux waveform, silicon steel strip, magnetostriction, wound-core type transformer, noise

In the design of transformer core, it is important to understand the relation between the magnetostriction characteristics of the raw materials and the noise of the core. This paper describes the influences of flux waveform on magnetostriction of silicon steel strip and noise of transformer core. In the analysis, input voltage $v$ and flux density $B$ are expressed by

$$
\begin{aligned}
& v(t)=V_{1} \cos \omega t+V_{3} \cos \left(3 \omega t+\theta_{3}\right) \\
& B(t)=B_{1} \sin \omega t+\sum_{n=2}^{M} B_{n} \sin \left(n \omega t+\theta_{n}\right)
\end{aligned}
$$

The magnetostriction characteristics under a sinusoidal-flux condition are expressed by

$$
\begin{aligned}
& \lambda=f(B(t))=\lambda_{0}+\sum_{k=1}^{K}\left(\lambda_{c k} \cos k \phi+\lambda_{s k} \sin k \phi\right) \\
& \phi=\sin ^{-1}(B(t) / B m) \ldots \ldots \ldots \ldots \ldots \ldots \ldots \ldots \ldots \ldots \ldots \ldots \ldots \ldots
\end{aligned}
$$

Here, $\lambda$ is magnetostriction, $\lambda_{c k}, \lambda_{s k}$ is the k-time harmonic component of magnetostriction, $B_{m}$ is the maximum flux density.

The relation between flux waveform and the harmonic component of magnetostriction under a non-sinusoidal flux condition are expressed by

$$
\begin{aligned}
& \lambda_{s k}=\left\{\sum_{U=0}^{W-1} f\left(B_{U}\right) \cdot \sin 2 \pi k U / W\right\} 2 / W \\
& \lambda_{c k}=\left\{\sum_{U=0}^{W-1} f\left(B_{U}\right) \cdot \cos 2 \pi k U / W\right\} 2 / W
\end{aligned}
$$

Here, $W$ is the number of partitions for period $2 \pi$ and $U$-th flux density is expressed by $B_{U}$.

Figure 1 shows the relation between harmonic components of magnetostriction and flux waveform. Fig. 1(a) shows the relations between $V_{3} / V_{1}$ and harmonic components of magnetostriction $\lambda_{k}$ in the case of $\theta_{3}=0$. Fig. 1(b) shows the relations between $V_{3} / V_{1}$ and harmonic components of magnetostriction $\lambda_{k}$ in the case of $\theta_{3}=\pi$. The analytical results agree roughly with the experimental results, it is shown that harmonic components of magnetostriction varies depending on the flux waveform.

Fig. 2 shows the relations between $V_{3} / V_{1}$ and noise $\mathrm{Nrms}$. In the case of $\theta_{3}=\pi$, noise increases as $V_{3} / V_{1}$ becomes larger. In the case of $\theta_{3}=0$, the value of $V_{3} / V_{1}$ which minimize noise is shown. These are mainly due to the fact that high harmonic component of magnetostriction varies depending on the flux waveform. The results obtained are useful in the design of the transformer.

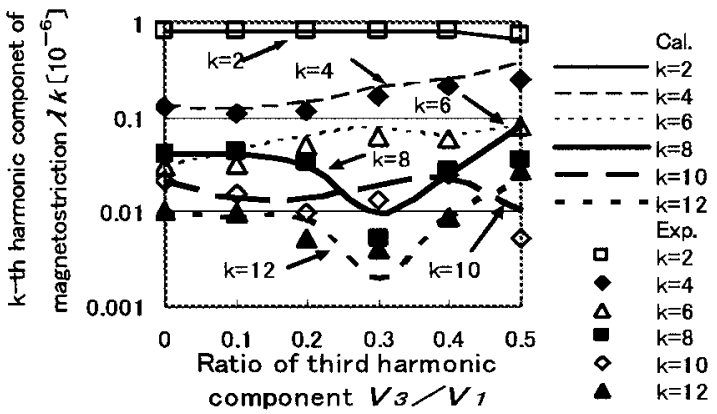

(a) $\theta_{3}=0$

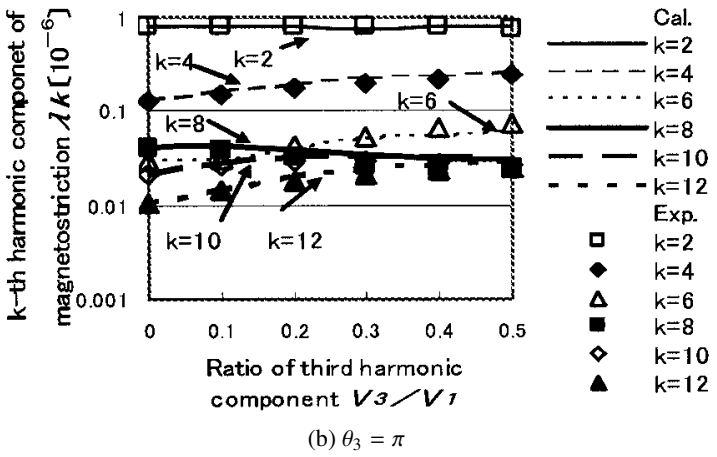

Fig. 1. Relation between $V_{3} / V_{1}$ and harmonic components of magnetostriction $\lambda_{k}$. (raw materials: 27P100, $f=60 \mathrm{~Hz}, B_{m}=1.7 \mathrm{~T}$ )

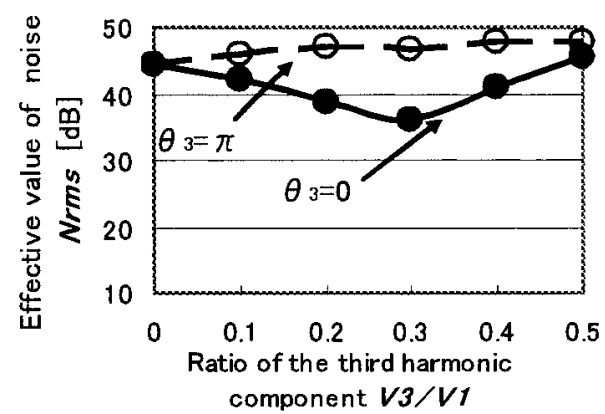

Fig. 2. Relation between $V_{3} / V_{1}$ and noise Nrms. (raw materials: 27P100, $f=60 \mathrm{~Hz}, B_{m}=1.7 \mathrm{~T}$ ) 


\title{
磁束波形が磁歪特性および変圧器鉄心の騒音に与える影響
}

\author{
正 員 新谷 邦弘* 正 員 斉藤 弘一* \\ Influences of Flux Waveform on Magnetostriction of Silicon Steel Strip \\ and Noise of Transformer Core
}

Kunihiro Shinya*, Member, Koichi Saito*, Member

\begin{abstract}
The influence of flux waveform on magnetostriction of silicon steel strip and noise of transformer core are described. In the analysis the magnetostriction characteristics under a sinusoidal-flux condition are approximated by Fourie series. By the numerical analysis relations between the flux waveform and the magnetostriction waveform are obtained. The analytical results agree roughly with the experimental results, it is shown that harmonic components of magnetostriction varies depending on the flux waveform. The relation between flux waveform and noise of the core are also obtained by the experiments, it is shown that noise of the core differs depending on the flux waveform. These are mainly due to the fact that harmonic components of magnetostriction varies depending on the flux waveform.
\end{abstract}

キーワード : 磁束波形, けい素鋼帯, 磁歪, 変圧器鉄心, 騒音

Keywords: flux waveform, silicon steel strip, magnetostriction, transformer core, noise

\section{1. まえがき}

変圧器の小型, 軽量, 高効率化とともに低騒音化が必要 とされている。変圧器の設計に当たって, 動作磁束密度を 高くとることにより小型, 軽量化を図ることができるが, 同 時に変圧器騒音を増大させることになるために，これを軽 減する方策が必要となる。変圧器の騒音は, 材料の磁歪に よる鉄心の振動によるもののほか, 電力用で使用される積 層鉄心では鉄心接合部のギャップでの電磁力, 積層板間の わたり磁束により生ずる電磁力等各種の原因により発生す る(1)(2)。鉄心内では磁束分布の不均一や磁束波形のひずみ を生じ, 磁歪特性はその影響を受ける ${ }^{(3)(4)}$ ため, 磁束波形 と磁歪および騷音特性との関係を知る必要があるが明らか にされていない。

本文は, 変圧器鉄心の騒音の基礎を得ることを目的とし て, 磁束波形が方向性けい素鋼帯の磁歪特性に与える影響 および方向性けい素鋼帯を用いた鉄心の磁歪特性と騒音と の関係について検討した結果を述べたものである(5)。磁束 波形と磁歪特性との関係について検討するに当たっては, 磁束正弦波条件で測定した磁歪特性をフーリエ級数で近似 してひずみ波磁束における磁歪特性を求めている ${ }^{(6)}$ 。また, 磁束波形と磁歪による騒音との関係について検討するに当 たっては，鉄心内の磁束分布の不均一や磁束波形のひずみ

\footnotetext{
* 福井工業高等専門学校

干 916-8507 鯖江市下司町

Fukui National College of Technology

Geshi-cho, Sabae-City, Fukui 916-8507
}

の影響が少なくし, さらに，ギャップでの電磁力に基づく 振動の発生がなく, 積層方法等鉄心構成に起因するものを 分離する必要がある。このため, ここでは, 鉄心接合部の ギャップがない理想的閉磁路構造であるために鉄心の磁歪 に起因する騒音のみについて把握でき, 磁束の不均一の少 ない寸法比 ${ }^{(7)}$ の巻鉄心を用いて実験により磁束波形と騒音 の関係を検討している。これらの結果から磁束波形が磁歪 高調波成分に与える影響を示し, 磁歪特性と騒音特性との 関係を明らかにしている。

\section{2. 磁束波形と磁歪特性}

〈2・1〉 解析方法 ここでは, 磁束正弦波で測定した磁 歪特性を用いてひずみ波磁束における磁歪特性を求めるこ ととし, 単板試料を用いた磁束密度 $B$ と磁歪 $\lambda$ の関係の測 定結果の一例を図 1 に示す。ただし, 材質は方向性けい素 鋼帯 27P110, 幅 $0.1 \mathrm{~m}$, 長さ $0.3 \mathrm{~m}$, 単板測定装置仕様は JIS 規格 ${ }^{(8)}$ に拠ったものを使用している。また, 磁歪は半 導体ゲージ（抵抗 $130 \Omega$, 長さ $6 \mathrm{~mm}$, ゲージファクタ 130) を試料に貼付して測定し, 磁束密度はさぐりコイルの誘導 起電力から算定する。いずれも 12 bit の波形記憶装置に取 り込み, バソコンにより波形分析を行い, ノイズ除去のた め 240 回のアベレージングを行っており, サンプリング周 波数は $10 \mathrm{kHz}$ である。最大動作磁束密度 $B m$ を一定とし た周波数 $f$ と磁歪の各調波成分 $\lambda_{k}$ ( $k$ は次数) との関係を 図 2 に示す。この範囲では周波数に対する磁歪の各調波成 分の変化は比較的少ないと言える。したがって, 最大動作 磁束密度 $B m$ における磁歪特性は (1) 式で表されるものと 
する。

$$
\left.\begin{array}{l}
\lambda=f(B(t))=\lambda_{0}+\sum_{k=1}^{K}\left(\lambda_{c k} \cos k \phi+\lambda_{s k} \sin k \phi\right) \\
\phi=\sin ^{-1}(B(t) / B m)
\end{array}\right\}
$$

ただし， $\lambda_{0}$ は磁歪の直流成分， $\lambda_{c k}$ は $k$ 次の余弦項のフー リ土係数, $\lambda_{s k}$ は $k$ 次の正弦項のフーリ工係数で, $K$ は磁束 正弦波に打ける磁歪特性を近似するのに考慮すべき高調波 の次数を示し, 以下に扔いてこれらの係数は $f=60 \mathrm{~Hz}$ に おける值を使用するものとする。なお，図 2 のように，実 際の動作領域である $B m \leqq 1.7 \mathrm{~T}$ では磁歪調波成分は高次 のものほど少なくなり，14 次以上の調波成分の割合は基本 波成分の $1 \%$ 以下であるため，解析では第 12 高調波までを 考慮 $(K=12)$ する ${ }^{(5)}$ 。

次に，ひずみ波磁束に押ける磁歪特性の計算方法 (6) につ いて述べる。電圧㧍よび磁束波形は (2) 式であらわされる ものとする。ただし， $M$ は電圧波形の考慮すべき高調波次 数を示す。

$$
\left.\begin{array}{l}
v(t)=V_{1} \cos \omega t+\sum_{n=2}^{M} V_{n} \cos \left(n \omega t+\theta_{n}\right) \\
B(t)=B_{1} \sin \omega t+\sum_{n=2}^{M} B_{n} \sin \left(n \omega t+\theta_{n}\right)
\end{array}\right\}
$$
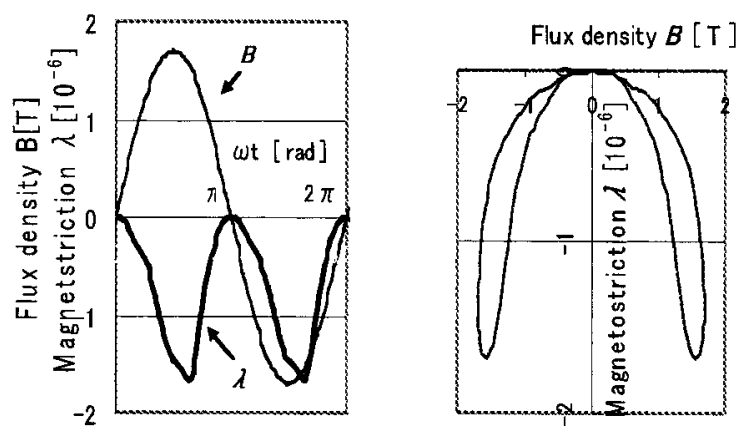

図 1 磁歪特性

$(f=60 \mathrm{~Hz}, B m=1.7 \mathrm{~T}$, material 27P110 $)$

Fig. 1. Magnetostriction characteristics $\lambda$.

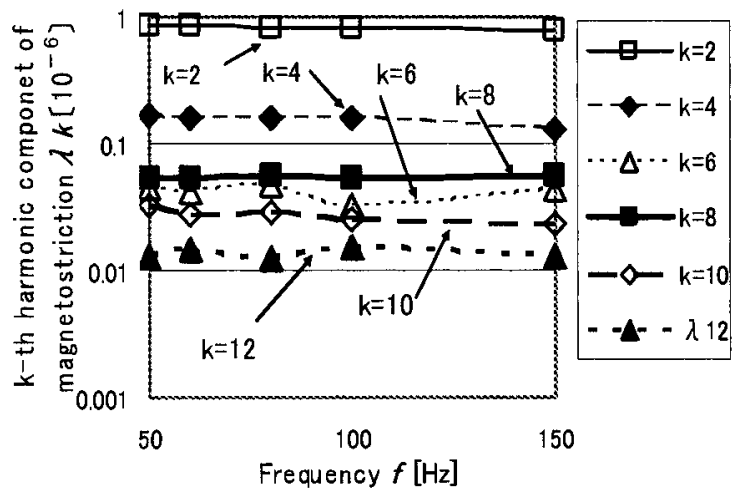

図 2 周波数 $f$ と $k$ 次磁歪調波成分 $\lambda_{k}$ との関係

$(B m=1.7 \mathrm{~T}$, material 27P110)

Fig. 2. Relation between frequency $f$ and $k$-th harmonic component of magnetostriction $\lambda_{k}$.
この時, (2) 式で与えられる磁束波形で励磁した場合の磁歪 の瞬時波形は (1) 式を用いて離散化して求めることができ, 離散的フーリェ変換を行うことにより第 $k$ 次調波成分 $\lambda_{c k}$, $\lambda_{s k}$ が得られ (3) 式となる。ただし, 離散化する場合の一周 期の分割数を $W, W$ 個に分割した $U$ 番目の位相角におけ る磁束密度 $B$ を $B_{U}$ とする。

$$
\begin{aligned}
& \lambda_{s k}=\left\{\sum_{U=0}^{W-1} f\left(B_{U}\right) \cdot \sin 2 \pi k U / W\right\} 2 / W \\
& \lambda_{c k}=\left\{\sum_{U=0}^{W-1} f\left(B_{U}\right) \cdot \cos 2 \pi k U / W\right\} 2 / W .
\end{aligned}
$$

$\langle\mathbf{2} \cdot \mathbf{2}\rangle$ 磁歪特性の解析および実験結果 磁束波形が 磁歪特性に与える影響について解析および実験により検討 した結果を示す。解析に当たっては, 離散化する場合の一 周期の分割数は $W=128$ とした。なお, 磁歪特性の測定 装置，方法は〈2・1〉節と同様である。また，以下において 最大磁束密度 $B m=1.7 \mathrm{~T}$ 一定の条件で電圧の基本波成分 に 3 倍高調波成分のみを重畳させ，(2) 式の基本波成分の振 幅 $V_{1}$ と 3 倍高調波成分の振幅 $V_{3}$ との比（以下 3 倍高調波 振幅比と呼ぶ） $V_{3} / V_{1}$ を $0.3 ， 3$ 倍高調波成分の位相角（以 下 3 倍高調波位相角と呼ぶ） $\theta_{3}$ を変化させた場合の結果を 示す。

3 倍高調波振幅比 $V_{3} / V_{1}=0.3,3$ 倍高調波位相角 $\theta_{3}$ を 0 および $\pi$ とした場合の磁束密度波形 $B$ および磁歪波形 $\lambda$ を

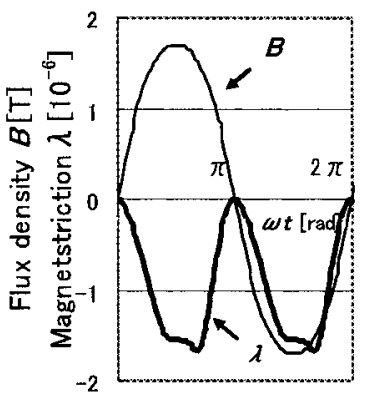

$V_{3} / V_{1}=0.3, \quad \theta_{3}=0$

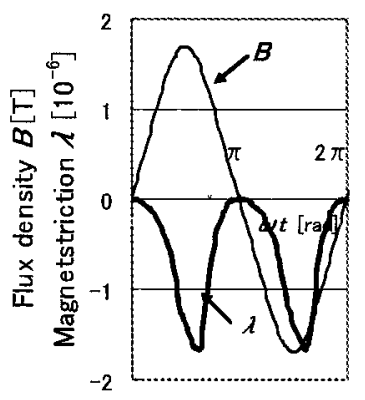

$V_{3} / V_{1}=0.3, \quad \theta_{3}=\pi$ (a) 実験結果

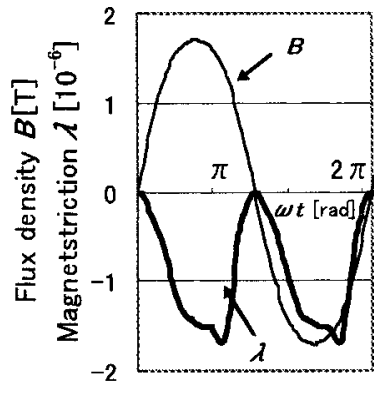

$V_{3} / V_{1}=0.3, \quad \theta_{3}=0$

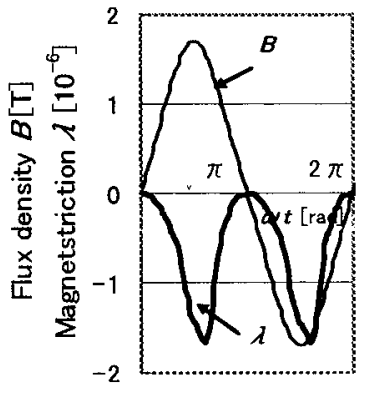

$V_{3} / V_{1}=0.3, \quad \theta_{3}=\pi$

(b) 計算結果

図 3 磁歪波形 $(f=60 \mathrm{~Hz}, B m=1.7 \mathrm{~T}$ 一定, material 27P110)

Fig. 3. Wave forms of magnetostriction $\lambda$. 


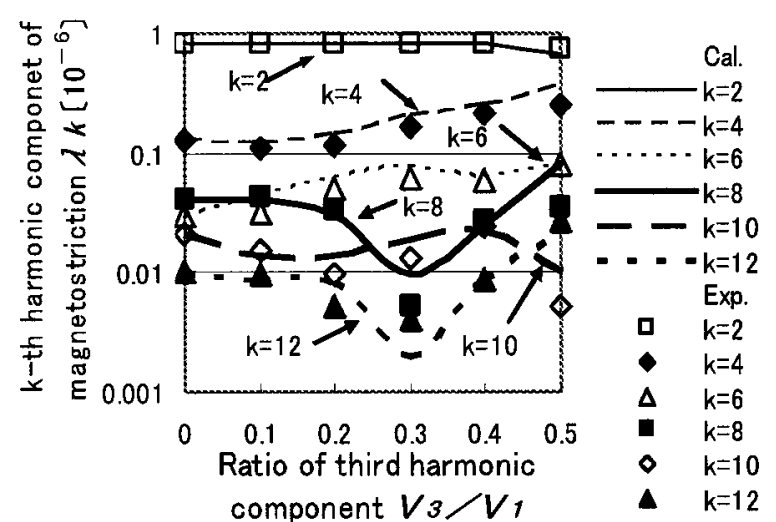

(a) $\theta_{3}=0$

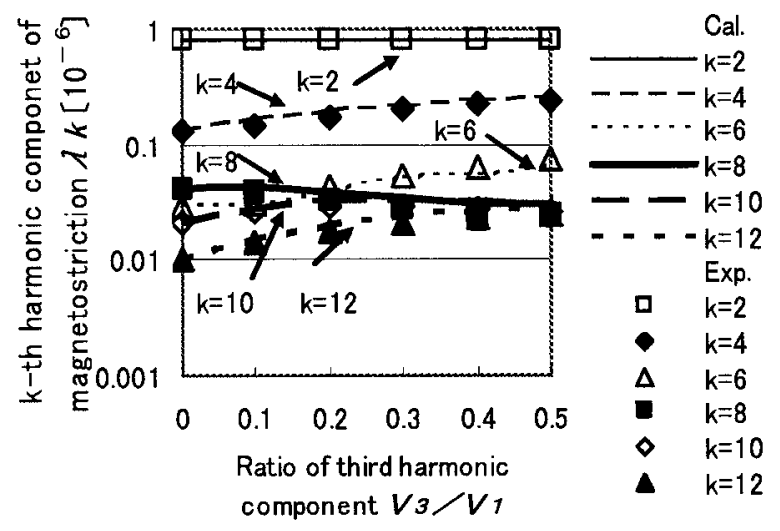

(b) $\theta_{3}=\pi$

図 43 倍高調波振幅比 $V_{3} / V_{1}$ と $k$ 次磁歪調波成分 $\lambda_{k}$ の 関係 $(f=60 \mathrm{~Hz}, B m=1.7 \mathrm{~T}$, material 27P110 $)$

Fig. 4. Relation between $V_{3} / V_{1}$ and $k$-th harmonic components of magnetostriction $\lambda_{k}$.

正弦波磁束の場合と比較して図 3 に示す。磁歪波形の計算 結果は実験結果とほぼ一致しており，本解析モデルにより， 磁束波形と磁歪波形の関係の検討ができる。図は，3 倍高 調波位相角 $\theta_{3}$ が 0 と $\pi$ の場合では磁歪波形は異なり，磁束 波形により磁歪波形は変化することを示している。

3 倍高調波位相角 $\theta_{3}$ を 0 および $\pi$ とし， 3 倍高調波振幅 比 $V_{3} / V_{1}$ を変化させた時の磁歪の $k$ 次調波成分 $\lambda_{k}$ を図 4 に示す。ただし，計算結果を線，実験結果をマークで示し ている。図に挍いて，電源周波数の 10 倍程度以下の調波 成分については解析結果と実験結果はほぼ一致しているが, これより高次のものでは差異を生じている。この原因とし て, 磁歪の高次の成分は基本波成分に比較して小さいため 測定誤差が含まれることおよび磁束波形がひずみ波となり， 磁化速度が変化した場合の磁歪特性は正弦波磁束の場合と 幾分異なることが挙げられる。さらに，磁束波形ひずみが 顕著な場合には磁歪特性（ $B$ - $\lambda$ 特性）にマイナーループを 生ずることを計算では考慮していないことも差異を生ずる 原因となり，詳細についてはさらに検討する必要がある。 図 5 は，磁歪の各調波成分は磁束波形により変化し，3 倍 高調波位相角 $\theta_{3}=\pi$ では 3 倍高調波振幅比 $V_{3} / V_{1}$ が大き くなると増加する成分が多いのに対し， $\theta_{3}=0$ では極小值

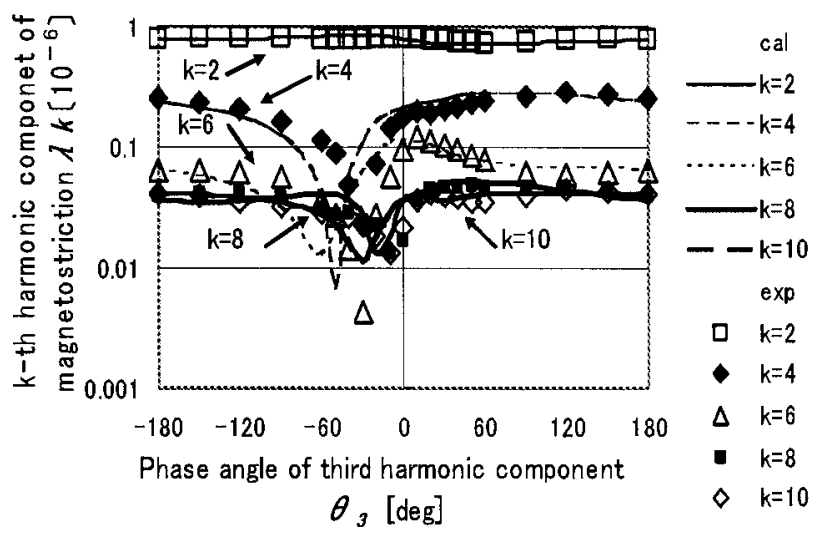

図 53 倍高調波位相角 $\theta_{3}$ と磁歪調波成分 $\lambda_{k}$ の関係 $\left(f=60 \mathrm{~Hz}, B m=1.7 \mathrm{~T}, V_{3} / V_{1}=0.3\right.$, material 27P110)

Fig. 5. Relation between $\theta_{3}$ and harmonic components of magnetostriction $\lambda_{k}$.

を有する傾向となる成分が多いことを示している。

3 倍高調波振幅比 $V_{3} / V_{1}$ を 0.3 として 3 倍高調波位相角 $\theta_{3}$ を変化させた場合の磁歪の $k$ 次調波成分 $\lambda_{k}$ を図 5 に示 す。ただし，計算結果を線，実駼結果をマークで示してい る。図において, 各調波成分の計算結果と実験結果の間に 極小となる位相角のずれが見られ，極小值にも差異を生じ ているが傾向はほぼ一致している。差異を生ずる原因とし ては, 3 倍高調波振幅比 $V_{3} / V_{1}$ を変化させた場合と同様の ことが挙げられる。図は，この材質では各調波成分は 3 倍 高調波位相角 $\theta_{3}=0$ 度近傍で顕著に变化し, 極小となるこ とを示している。

\section{3. 磁束波形と騷音特性}

磁束波形が磁歪による鉄心の騒音特性に与える影響につい て実験により検討した結果を述べる。実験には図 6 のギャッ プのない角形巻鉄心（接着剂含浸なし）に巻数 $N_{1}=50$ 回 の励磁コイルおよび $N_{2}=10$ 回のさぐりコイルを施したも のを使用した。また，騒音は暗騒音 $20 \mathrm{~dB}$ の無響室におい て精密騒音計（RION 製 NL-14，周波数補正 A 特性）によ り測定した。なお，騒音は測定位置により幾分差異を生ず るため,ここではほほ平均的な值が得られる鉄心中央部で 鉄心前方 $0.1 \mathrm{~m}$ の位置で測定している。なお，以下に抏い て, 最大磁束密度 $B m=1.7 \mathrm{~T}$ 一定として電圧の基本波成分 に第 3 高調波成分のみを重目させ， 3 倍高調波振幅比 $V_{3} / V_{1}$ および 3 倍高調波位相角 $\theta_{3}$ を変化させた磁束波形における 騒音特性を示す。

正弦波磁束で電源の周波数 $f$ を変化させた場合の騒音の 実効值 Nrms 拈よび騒音の $k$ 次調波成分 $N_{k}(k=2,4,6, \cdots)$ を図 7 に示す。図に抒いて $f=60 \mathrm{~Hz}$ では電源の数倍から 10 数倍程度の成分が主である。そして, 騒音は, $f=60 \mathrm{~Hz}$ では $k=8, f=80 \mathrm{~Hz}$ では $k=6, f=120 \mathrm{~Hz}$ では $k=4$, すなわちほほ $480 \mathrm{~Hz}$ 近傍の成分が最大となっている。図 2 に示したように周波数を变化させた場合の磁歪調波成分の 


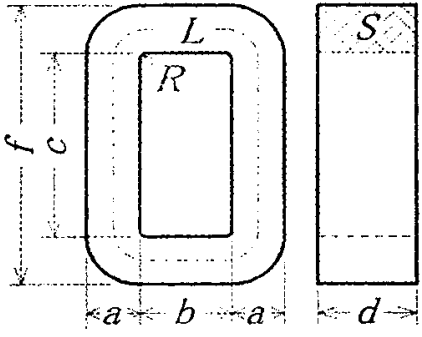

$\mathrm{a}=0.025 \llbracket \mathrm{m}\rceil, \mathrm{b}=0.076\lceil\mathrm{~m}\rceil, \mathrm{c}=0.205 \llbracket \mathrm{m}\rceil, \mathrm{d}=0.10\lceil\mathrm{~m}\rceil$ $\mathrm{N}_{1}=50$ (turn), $\mathrm{N}_{2}=50$ (turn), material 27P110

図 6 巻鉄心寸法

Fig. 6. Dimension of the core.

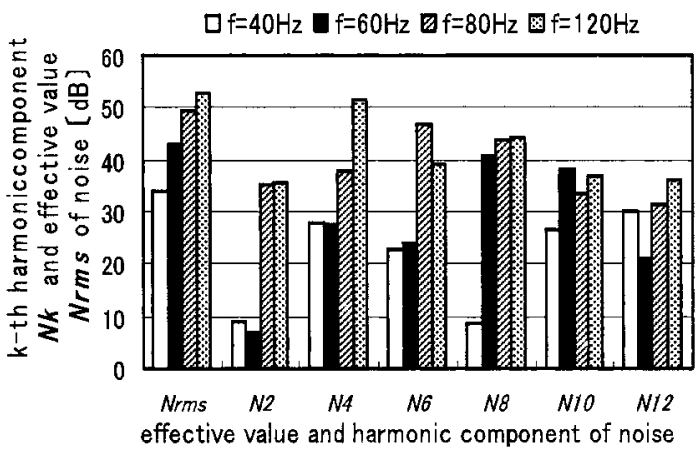

図 7 周波数変化時の騒音の $\mathrm{k}$ 次調波成分 $N_{k}$ と 騒音実効值 Nrms $\quad(B m=1.7 \mathrm{~T} ， 27 \mathrm{P} 110 ）$

Fig. 7. $k$-th harmonic components $N_{k}$ and effective value $\mathrm{Nrms}$ of noise.

変化は少ないことから，これは，鉄心の寸法比等で定まる 機械的固有振動数が $480 \mathrm{~Hz}$ 近傍にあるためと考えられる。 磁束密度波形 $B$ および騒音波形 $N$ を図 8 に示す。図よ り，騒音波高值は正弦波磁束の図 (a) の場合に比べ，図 (b) の 3 倍高調波振幅比 $V_{3} / V_{1}=0.3,3$ 倍高調波位相角 $\theta_{3}=0$ では減少し，一方図 (c) の $V_{3} / V_{1}=0.3, \theta_{3}=\pi$ では増加す るなど磁束波形により騒音波形は変化することがわかる。

3 倍高調波位相角 $\theta_{3}=0$ および $\pi$ とし， 3 倍高調波振幅 比 $V_{3} / V_{1}$ を変化させた場合の騒音の実効值 $N r m s$ を図 9 に 示す。図は，最大磁束密度が一定の場合磁歪による騒音は 磁束波形（高調波成分の位相，振幅）により異なることを 示している。すなわち，この材質では磁束波形のひずみが 増した場合の磁歪による騷音は正弦波磁束の場合より増加 する場合と正弦波磁束の場合より減少して極小值を有する 傾向となる場合があることがわかる。

これらの磁束波形による騒音実効值の变化についてさら に詳しく検討するために，3 倍高調波位相角 $\theta_{3}$ を 0 および $\pi$ とし 3 倍高調波振幅比 $V_{3} / V_{1}$ を変化させた場合の騒音の $k$ 次調波成分 $N_{k}$ を図 10 に示す。図に扔いて騒音の主要な 成分は鉄心の固有振動数近傍に相当する電源周波数 $f$ の 8 , 10 倍の騒音調波成分 $N_{8}, N_{10}$ であり，騒音の実効值の変化 はこれらの調波成分の変化に依存している。そして，3 倍高 調波位相角 $\theta_{3}=0$ の場合における騒音の減少はこれらの騒 音調波成分が小さくなったためであることがわかる。図 10

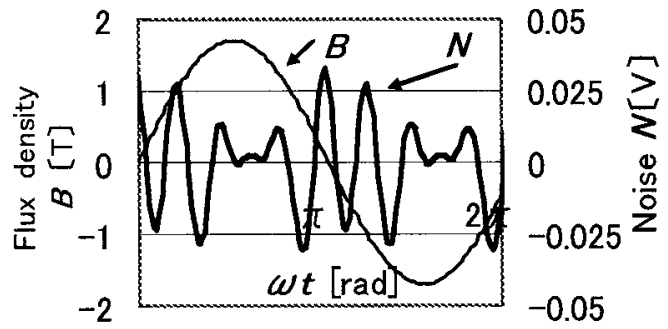

(a) $V_{3} / V_{1}=0$

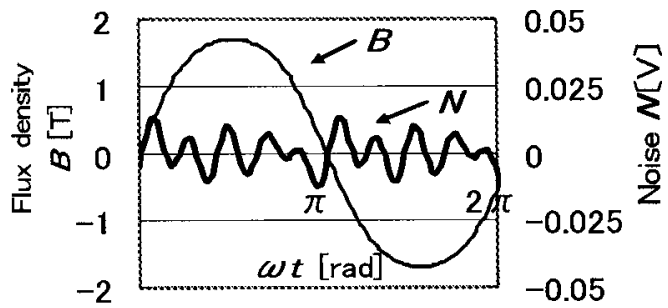

(b) $V_{3} / V_{1}=0.3, \theta_{3}=0$

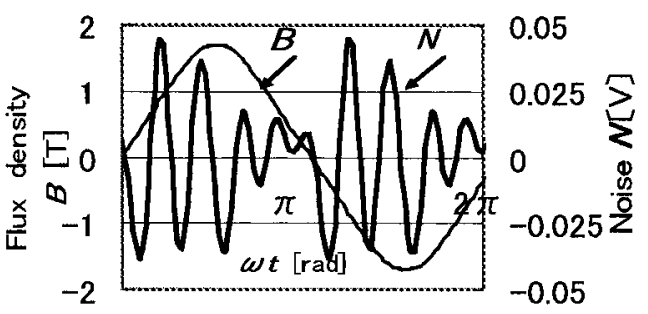

(c) $V_{3} / V_{1}=0.3, \theta_{3}=\pi$

図 8 磁束密度波形 $B$ および騒音波形 $N(0.01$ Vrms $: \mathrm{N}=40 \mathrm{~dB})(f=60 \mathrm{~Hz}, B m=1.7 \mathrm{~T}$, material 27P110)

Fig. 8. Wave forms of noise ( $\mathrm{N}=40 \mathrm{~dB}$ : $0.01 \mathrm{Vrms})$.

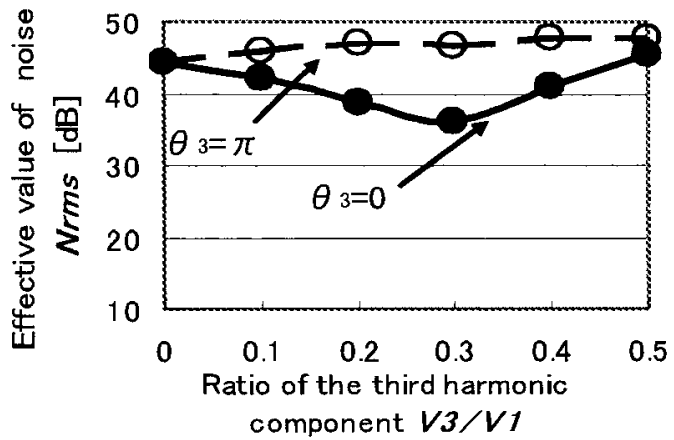

図 93 倍高調波振幅比 $V_{3} / V_{1}$ と騒音実効值 $\mathrm{Nrms}$ との関係 $(f=60 \mathrm{~Hz}, B m=1.7 \mathrm{~T}$ 一定, material 27P110)

Fig. 9. Relation between $V_{3} / V_{1}$ and effective value of noise Nrms.

の 3 倍高調波振幅比 $V_{3} / V_{1}$ の変化に対する騒音調波成分の 変化と図 4 の磁歪調波成分の変化を比較すると，3 倍高調 波位相角 $\theta_{3}=0$ の場合には電源周波数の 8,10 倍等の調波 成分が極小值を有する傾向となるのに対し， $\theta_{3}=\pi$ では変 化が少ないことなど $V_{3} / V_{1}$ の変化に対する騒音と磁歪の各 調波成分の変化はほぼ同じ傾向を示すことがわかる。

3 倍高調波振幅比 $V_{3} / V_{1}$ を 0.3 一定として 3 倍高調波位 


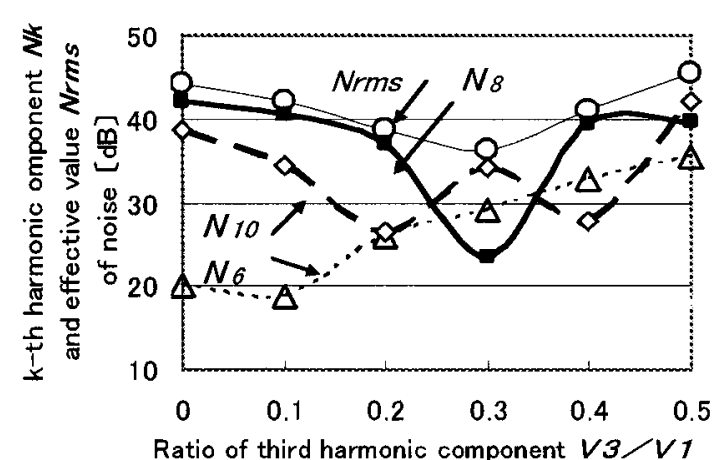

(a) $\theta_{3}=0$

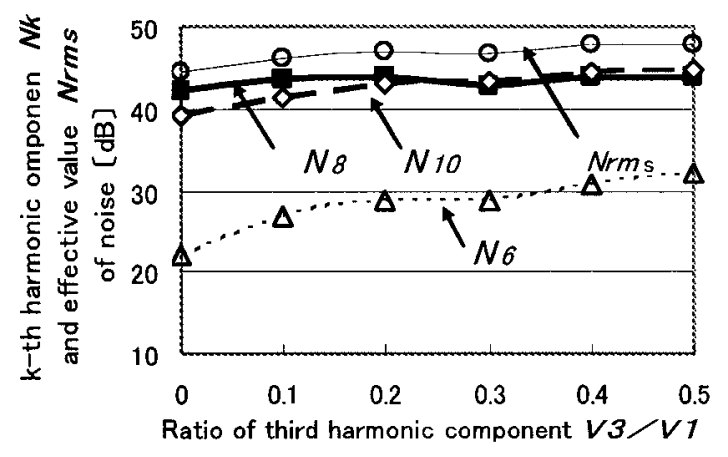

(b) $\theta_{3}=\pi$

図 103 倍高調波振幅比 $V_{3} / V_{1}$ と騒音の $k$ 次高調 波成分 $N_{k}$, 騒音実効值 $N r m s$ との関係 $(f=60 \mathrm{~Hz}$, $B m=1.7 \mathrm{~T}$, material 27P110)

Fig. 10. Relation between $V_{3} / V_{1}$ and $k$-th harmonic components $N_{k}$ and effective value Nrms of noise.

相角 $\theta_{3}$ を変化させた場合の騒音の $k$ 次調波成分 $N_{k}$, 騒音 実効值 Nrms を図 11 に示す。図よりこの材質の場合には 3 倍高調波位相角 $\theta_{3}=0$ 近傍で騒音実効値は極小となる傾 向を示すことがわかる。また，電源周波数の 8，10 倍の騒 音調波成分の割合が大きく，騒音実効值が極小となるのは， これらの調波成分が極小となるためであることがわかる。 図 11 の騒音の調波成分の変化を図 5 の磁歪の調波成分の 変化と比較すると, 極小となる 3 倍高調波位相角 $\theta_{3}$ に差異 が見られるものの，磁歪および騒音の 8,10 倍の調波成分 はいずれも $\theta_{3}=0$ 近傍で極小となっており， $\theta_{3}$ の変化に対 する騒音と磁歪の各調波成分の変化はほぼ同じ傾向を示す ことがわかる。

この材質の場合に磁束波形と磁歪による騒音の関係が以 上のよう傾向を示す理由は以下のようである。磁歪 $\lambda$ が磁 束密度 $B$ の 2 乗に比例する特性を有する場合には, 磁束波 形が正弦波の時に磁歪波形は磁束の 2 倍の周波数の正弦波 となる。これに対し，この材質の正弦波磁束における磁歪 特性は図 1 に示したようにヒステリシスを有し，2 乗に比 例する特性とはならない。このため, 正弦波磁束における 磁歪波形はひずみ波となって磁束の周波数の 2 倍周波数成 分の他に偶数次の高調波成分を含む。磁束波形が変化する と磁歪波形は変化し，図 4, 図 5 に示したように磁歪の各 調波成分が極小となる磁束波形が存在する。このような磁

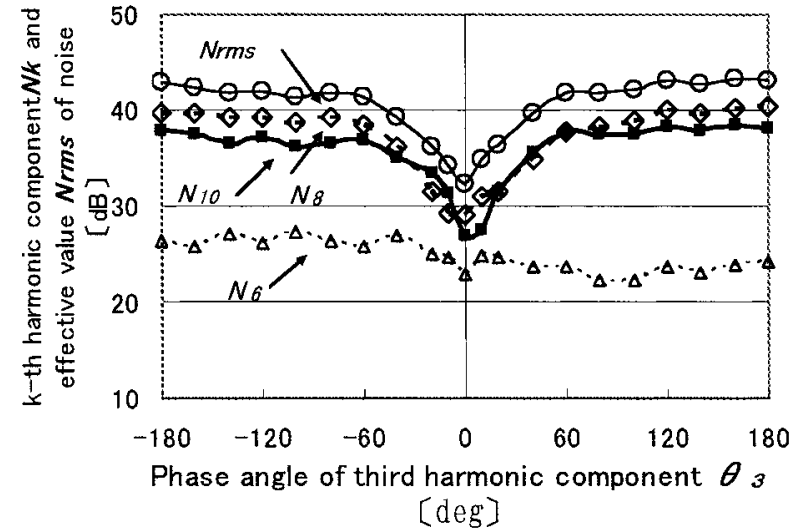

図 113 倍高調波位相角 $\theta_{3}$ と騒音の $k$ 次調波成分 $N_{k}$ ，騒音実効值 $N r m s$ との関係 $(f=60 \mathrm{~Hz}$, $B m=1.7 \mathrm{~T}, V_{3} / V_{1}=0.3$, material 27P110)

Fig. 11. Relation between $\theta_{3}$ and $k$-th harmonic components $N_{k}$ and effective value $N r m s$ of noise.

歪の各調波成分の変化に伴って騒音の各調波成分は変化し, 特に，鉄心の固有振動数近傍の騒音調波成分の振る舞いが 磁歪による騒音に大きな影響を与える。この材質で, 基本 波に 3 倍高調波成分のみを加えた場合に鉄心の固有振動数 近傍の磁歪調波成分が極小になる磁束波形は，3 倍高調波 位相角 $\theta_{3}=0,3$ 倍高調波振幅比 $V_{3} / V_{1}=0.3$ 近傍となる。 このため, この磁束波形において騒音も極小となる。した がって, 変圧器騒音を軽減するには鉄心の固有振動数近傍 の磁歪調波成分を少なくする必要がある。

\section{4. まと め}

磁束波形が方向性けい素鋼帯の磁歪特性に与える影響を 解析および実験により求めるとともに，磁束波形と鉄心の 磁歪による騒音特性との関係を実験により求めて磁歪特性 と騒音特性との関係を検討し, 次の結果を得た。

（1）正弦波磁束における磁束密度と磁歪との関係をフー リ土級数で近似し, 非正弦波磁束における磁歪波形を求め た結果, 電源周波数の 10 倍程度以下磁歪調波成分につい ては，解析結果は実験結果とほぼ一致する。

（2）動作最大磁束密度を一定として磁束波形（高調波 成分の位相, 振幅) を変化させると磁歪波形は変化し, 特に 電源周波数の数倍以上の磁歪調波成分の变化が顕著である。

（3）動作最大磁束密度を一定として磁束波形（高調波 成分の位相, 振幅) を変化させると磁歪による騒音は変化 し，騒音が極小となる磁束波形がある。

（4）磁歪調波成分の変化に伴って騒音調波成分は変化 し，特に鉄心の固有振動数近傍の周波数の磁歪調波成分が 鉄心騒音に与える影響が大きい。

以上の結果から, 磁歪による変圧器騒音の軽減を図るに は磁歪が小さいだけでなく鉄心の固有振動数近傍の磁歪調 波成分が少ない鉄心材質の開発 ${ }^{(9)}$ が必要である。また，こ の材質を磁束波形ひずみの少ない鉄心寸法比，積層法で使 
用することが重要である。

ここでは，磁束波形を変化することにより磁歪特性と磁 歪による変圧器鉄心の騒音との関係について定性的な検討 を行った結果を示した。騒音について定量的な検討を行う には，まず，素材の磁歪特性について高次の調波成分まで 含めた正確な測定をする必要がある。また，磁歪と鉄心の 振動との関係を把握することが必要となる。今後, さらに 他の材質について磁歪の高精度の測定を行い, 鉄心の騒音 特性との関係について詳細な検討を進めたい。

(平成 17 年 8 月 22 日受付, 平成 18 年 5 月 29 日再受付)

文献

(1) M. Mizokami, M. Yabumoto, and Y. Okazaki: "Vibration Analysis of 3Phase Model Transformer Core", T. IEE Japan, Vol.116-A, No.8, pp.744749 (1996-8) (in Japanese)

溝上雅人・藪本政男・岡崎靖雄 : 「三相モデル変圧器鉄心の振動解 析」, 電学論 A, 116, 8, pp.744-749 (1996-8)

(2) M. Ishida and K. Sato: "Influence of Higher Harmonics in Flux Density on Performance of Model 3-Phase Staked Transformer Core", The Paper of Technical Meeting on Magnetics, IEE Japan, MAG-96-105 (1996) (in Japanese)

石田昌義・佐藤圭司：「三相積変圧器モデル鉄心特性に及ぼす磁束 高調波の影響」, 電学マグネティックス研資, MAG-96-106 (1996)

(3) H. Nagae, I. Komatsu, H. Watanabe, and T. Toda: "Comparison of Core Loss and Noise Level between Single-Phase Two-limbed Cores and Threephase Two-limbed Cores", The Paper of Technical Meeting on Magnetics, IEE Japan, MAG-96-106 (1996) (in Japanese)

長江洋典・小松 嚴・渡辺弘行・戸田恒雄：「単相二脚鉄心と三相三 脚鉄心における鉄損および騒音特性の比較」, 電学マグネティックス 研資, MAG-96-106 (1996)

(4) J. Hirano, H. Ebina, Y. Ishihara, K. Harada, T. Todaka, T. Kageyama, and K. Shimizu: "Characteristics of Magnetostriction of Silicon Steel Sheet under PWM Excitation", Journal of the Japan Society of Applied Electromagnetics and Mechanics, Vol.12, No.4, pp.342-345 (2004) (in Japanese) 平野順平・海老名紘明・石原好之・原田和郎・戸高敏之・景山寿晴・ 清水 健:「PWM 波励磁下に打ける電磁鋼板の磁歪特性」, 日本 AEM 学会, 12, 4, pp.342-345 (2004)

(5) K. Sekimoto, K. Saito, and K. Shinya: "Influence of Input Voltage Waveform on Magnetostriction and Noise of Tape Wound Core", The Paper of Technical Meeting on Magnetics, IEE Japan, MAG-00-129 (2000) (in Japanese)

関本晃一・斉藤弘一・新谷邦弘：「電圧波形が巻鉄心の磁歪および騒 音に与える影響」, 電学マグネティックス研資, MAG-00-129 (2000)
(6) K. Shinya, K. Saito, T. Iwama, and E. Miyazawa: "Analysis of Magnetostriction of Silicon Steel Sheet under Non-Conventional Waveform", The Paper of Technical Meeting on Magnetics, IEE Japan, MAG-97-78 (1997) (in Japanese)

新谷邦弘·斉藤弘一・岩間貴之·宮沢永次郎：「非正弦波励磁下のけい素 鋼板の磁気ひずみ特性解析」, 電学マグネティックス研資, MAG-97-78 (1997)

(7) K. Saitho, K. Shinya, and E. Miyazawa: "Influence of Dimention Ratio and Magnetizing Conditions on the AC Magnetic Properties of Tape Wound Ring Core", T. IEE Japan, Vol.118-A, No.5, pp.490-495 (1998-5) (in Japanese)

斉藤弘一 一新谷邦弘・宮沢永次郎：「環状巻鉄心の交流磁気特性に与 える磁化条件と寸法比の影響」, 電学論 A, 118, 5, pp.490-495 (1998-5)

(8) "Method of Measurement of the Magnetic Prpperties pf Magnetic Steel Sheet and Strip by Means of a Sinle Sheet Tester", JIS C 2556 (1996) (in Japanese)

「電磁鋼板単板磁気特性試験方法」, JIS C 2556 (1996)

(9) M. Fujikura, S. Arai, and T. Kubota: "Effect of Laser Irradiation on the Magnetostriction of Grain-Oriented Electrical Steels", Journal of the Magnetics Society of Japan, Vol.25, No.4-2, pp.895-898 (2001) (in Japanese) 藤倉昌浩・新井 聡・久保田 猛：「レーザー照射による方向性電磁 鋼板の磁歪の变化」, 日本応用磁気学誌, 25, No.4-2, pp.895-898 (2001)

新 谷 邦 弘 (正員) 1946 年 12 月 1 日生。1970 年 3 月福井

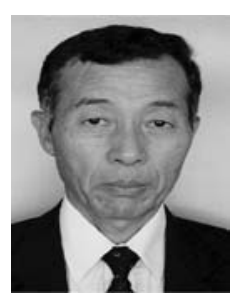
大学工学部電気工学科卒業。同年 4 月福井工業 高等専門学校電気工学科に勤務。主として，電気 機器鉄心の磁気特性解析に関する研究に従事。現 在, 同教授。工学博士。日本応用磁気学会会員。

斉 藤 弘 - (正員) 1952 年 5 月 9 日生。1971 年 3 月福井

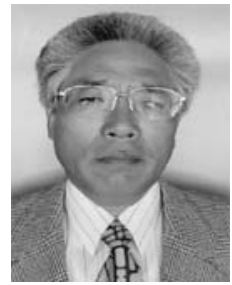
県立武生工業高等学校電気工学科卒業。同年 4 月 福井工業高等専門学校電気工学科に勤務。主とし て, 電気機器鉄心の磁気特性に関する研究に従事。 